\title{
Religious engagement and citizen support for democratic accountability in contemporary democracies
}

\author{
Aida Just \\ Bilkent University, 06800 Bilkent, Ankara, Turkey
}

\section{A R T I C L E I N F O}

\section{Keywords:}

Religion

Religiosity

Attendance of religious services

Democratic accountability

Economic evaluations

Just world beliefs

Government satisfaction

\begin{abstract}
A B S T R A C T
The paper posits that individual religious engagement reduces people's motivations to hold governments accountable for their performance while in office. This expectation is based on previous research which shows that religion is closely linked with believing that the world is just, a place where people generally get what they deserve and deserve what they get. Using data from the European Social Survey 2012-13 in seventeen established democracies, the study shows that individual religious engagement - in a form of religiosity and attendance of religious services - is indeed negatively associated with believing that governing parties should be punished in elections for poor performance. Moreover, while strong believers are more satisfied with government than non-believers, religious engagement weakens the relationship between people's economic evaluations and government satisfaction. These findings have important implications for debates on democratic accountability, reward-punishment models of electoral politics, and the prospects of democratic legitimacy in states with considerable shares of religious individuals.
\end{abstract}

Debates about democracy in western countries have become closely intertwined with discussions about the political consequences of religion. Questions have been asked whether religious beliefs, particularly Islam, are associated with the kind of orientations and behavior that are compatible with the functioning of democratic governance. Sceptics argue that whereas democracy requires pluralism, competition, and appreciation of diversity, religion often encourages an uncritical acceptance of authority and intolerance to opposing views (e.g., Gill, 2001, p. 127; Altemeyer, 1988, p. 230; Hunsberger, 1995, p. 124). Others point to a considerable variation within religious groups in their expression of support for various aspects of democracy (e.g., Tessler, 2002, p. 348; Tessler, 2010, p. 252), and argue that no religious doctrine has been univocally pro- or anti-democratic (Stepan, 2000, p. 44; Wald et al., 2005, p. 141). Moreover, there is evidence that the official positions of religious leaders towards democratic or dictatorial regimes have varied markedly across countries and over time, often as a consequence of strategic considerations to ensure the survival and political influence of religious institutions (e.g., Gill, 1998, p. 3; Kalyvas, 1996, pp. 258-61; Warner, 2000, p. 3).

Research on public opinion has recently sought to reassess what we know about the consequences of religion for democracy by distinguishing among various aspects of individual religious beliefs - most notably, attendance of religious services, individual religiosity, and belonging to various religious groups or denominations (e.g., Ben-Nun Bloom and Gizem, 2012a, p. 377; Meyer et al., 2008, p. 640; Patterson, 2004, p. 347). Yet, the results of these studies have been mixed. For example, Ben-Nun Bloom and Arikan (2012a, p. 397; 2012b, p. 268) show that social religious behavior (in a form of attendance of religious services and belonging to a religious organization) contributes positively to support for democracy, while individual religiosity has the opposite effect. In contrast, Meyer et al. (2008, p. 644) find that people's democracy attitudes are shaped by individual religiosity, but not by attendance of religious services.

There may be various reasons for why scholars arrived at different conclusions in these broadly cross-national studies. But perhaps

E-mail address: aidap@bilkent.edu.tr. 
chief among them is the fact that existing research so far has paid little attention to the possibility that religion may not have the same consequences for different aspects of democratic governance. One interesting finding that has emerged in several studies is that more devout individuals prefer democracy less, while at the same time they are more satisfied with the functioning of democracy and express more confidence in political institutions in their country than weak believers or non-believers (Patterson, 2004, p. 353; Hayes, 1995, p. 191). A good theory that could explain these seemingly contradictory results still eludes existing research, in large part because scholars have not devoted sufficient attention to the democratic phenomena under consideration.

To further our understanding in this direction, this study focuses on one fundamental aspect of democratic governance - government accountability - and systematically examines how people's support for it is linked to their religious engagement. Since the inception of modern (representative) democracy, many scholars have regarded accountability as key to democratic governance. This view is reflected in Schmitter and Karl (1991, p. 76) oft-cited definition of democracy: "Modern democracy is a system of governance in which rulers are held accountable for their actions in the public realm by citizens acting indirectly through the competition and cooperation of their elected representatives." Similarly, in Polyarchy, Dahl (1971, p. 3) notes that "at a minimum .... democratic theory is concerned with processes by which ordinary citizens exert a relatively high degree of control over leaders." Others add that "nothing is more fundamental to popular control than the idea that citizens hold government officials accountable for their collective actions" (Kuklinski and West, 1981, p. 437).

In analyzing the consequences of religion for people's support for democratic accountability, I focus on the degree of individual religious engagement, as reflected in one's religiosity and attendance of religious services, while accounting for people's belonging to religious groups or denominations. I posit that religious engagement contributes negatively to people's support for democratic accountability because religion is closely linked with the belief that the world is just, and that people generally get what they deserve and deserve what they get (e.g., Kaplan, 2012, p. 404; Overcash et al., 1996, p. 456; Rubin and Peplau, 1975, p. 78; Sorrentino and Hardy, 1974, p. 378; Szmajke, 1991, p. 40). This means that more devout believers are likely to attach less importance to punishing governing parties in elections for poor performance while in office than less religious or secular individuals.

The analyses of individual-level data collected as part of the European Social Survey (ESS) 2012-13 (round 6) in seventeen established democracies confirm these expectations. The results reveal that more intense religious engagement is indeed negatively related to believing that governing parties should be punished in elections when they have done a bad job while in office. Moreover, while strong believers are generally more satisfied with their national government than weak-believers or secular individuals (even when controlling for their partisan and ideological leanings), religious engagement weakens the relationship between people's evaluations of policy outcomes and satisfaction with their country's government.

This study contributes to existing research in several ways. First, the analyses highlight previously overlooked role that religion plays in shaping people's support for democratic accountability and government satisfaction. In doing so, the study aims to add to a still slim body of cross-national research on when and how religion matters in politics (Bellin, 2008; Grzymala-Busse, 2012; Wald and Wilcox, 2006). ${ }^{1}$ Second, the paper contributes to a growing number of systematic inquiries into the consequences of individual religious engagement, while at the same time accounting for people's affiliation with different religious groups or denominations (e.g., Ben-Nun Bloom and Gizem, 2012a; Eisenstein, 2006; Patterson, 2004). Third, whereas scholars have shown a considerable interest in how religion influences individual behavior leading to economic growth (e.g., Guiso et al., 2003; McCleary and Barro, 2006) and people's preferences for redistribution (e.g., Huber and Stanig, 2011; Scheve and Stasavage, 2006), we still lack knowledge on how religion contributes to people's support for various aspects of democratic governance. The study aims to fill this gap in the literature by focusing on democratic accountability - a feature of democratic governance of fundamental importance to democratic theory - and it does so by systematically analyzing citizens' support for government accountability both in principle and in practice.

The next section of the paper develops the main argument. I then describe my data and measures employed in the empirical analyses, and subsequently present the results. The final section discusses the implications of my findings and offers suggestions for further research.

\section{Religion, just world beliefs, and political attitudes}

While democratic accountability has long been the focus of scholarly attention, few studies have considered the strength of religious beliefs and practices among its possible determinants. One possible reason for this neglect is that for most of the 20th century the processes of modernization and secularization were expected to diminish the strength of religious identities and their relevance in contemporary politics (cf., Bellin, 2008, p. 317; Norris and Inglehart, 2011, p. 3). Research shows that people's attendance of religious services has indeed declined in many post-industrial societies, although it remains remarkably high in some countries, such as Ireland, the United States, and Italy (Norris and Inglehart, 2011, p. 60). ${ }^{2}$ In addition, studies of electoral politics confirm that religion continues structuring people's party preferences and ideological orientations as well as their voting turnout and choices at the ballot box (Botterman and Hooghe, 2012, p. 13; Elff and Roßteutscher, 2011, p. 124; Knutsen, 2004, p. 121; KotlerBerkowitz, 2001, p. 552; Norris, 2004, pp. 113-4; Norris and Inglehart, 2011, pp. 201-8; Raymond, 2011, p. 132; van der Brug et al., 2009, p. 1280; Tilley, 2015, pp. 922-3). There is also evidence that religiosity has become a more important predictor of citizen

\footnotetext{
${ }^{1}$ For studies on the determinants of individual religious beliefs and practices, see, for example, Voas (2009), Ruiter and van Tubergen (2009), Aarts et al. (2008), and Need and de Graaf (1996).

${ }^{2}$ The sources of this decline, however, remain a matter of scholarly debate. Some scholars challenge the secularization theory, arguing that there has been no decline in religious participation in response to modernization (Stark, 1999, p. 249; Greeley, 2003, pp. 214-5), and that state regulation of religion and competition among religious groups provide a better explanation why people's religious engagement varies across countries and over time (e.g. Stark and Finke. 2000, p. 22).
} 
electoral behavior than belonging to a particular religious group or denomination (Layman, 1997, p. 306; Minkenberg, 2010, p. 408).

In light of these findings, we have reasons to suspect that religion influences citizens' attitudes towards their governments in contemporary democracies. I posit that since religion is closely linked to just world beliefs, religious engagement shapes people's opinions about their governments in at least two ways. First, it encourages individuals to express more satisfaction with their governments. At the same time, religious engagement weakens the kind of views and behavior that are necessary to hold governments accountable for their performance while in office. The latter means not only that more devout believers are less likely to attach importance to punishing governing parties in elections for bad performance, but also that religious engagement moderates the extent to which people connect their evaluations of government performance to satisfaction with their national governments.

Religious engagement matters for people's attitudes and behavior in politics because it offers individuals not only behavioral guidelines on how to cope with the outside world, especially in times of adversity, but also cognitive tools in the form of a comforting and compelling worldview that helps believers to explain the occurrence of such adversity (e.g., Pargament, 1997, p. 3; Pargament and Hahn, 1986, p. 205; Rubin and Peplau, 1975, p. 84). At the center of such worldview is seeing God (or divine forces) as the ultimate source of power, capable of correcting all injustices and rewarding people for leading virtuous lives. In line with this perspective, religion has been found to be closely linked with believing that the world is just, and that people generally get what they deserve and deserve what they get (e.g., Kaplan, 2012, p. 404; Overcash et al., 1996, p. 456; Rubin and Peplau, 1975, p. 78; Sorrentino and Hardy, 1974, p. 378; Szmajke, 1991, p. 40). ${ }^{3}$ These beliefs tend to be resilient to change, as they provide people with a useful psychological buffer in dealing with the outside world and give individuals a stronger sense of control over their own lives (Furnham, 2003, p. 796). Believing that the world is just (or made just by divine intervention) reduces people's perceptions of threat and risk to become a victim of adversity, since most people think they have done nothing to deserve it. Moreover, when someone becomes a victim of adversity, just world beliefs encourage people to see such outcomes as deserved, weakening their motivations to act in response to adversity or consider a wider range of its possible causes.

\section{Religious engagement and government satisfaction}

I argue that the consequences of just world beliefs extend to the political sphere of society and play an important role in shaping people's attitudes towards their governments and democratic accountability. Since religious people believe that the world is just, they are more likely to think that individuals who occupy powerful positions in fact deserve being there. Existing research shows that people with strong beliefs in a just world are indeed more likely to admire and support those in power and are less likely to express suspicion or cynicism about government activities (cf., Rubin and Peplau, 1975, pp. 81-2). Consistent with this perspective, some studies show that believers have more confidence in political institutions and are more satisfied with the political system than nonbelievers (Anderson and Singer, 2008, p. 581; Patterson, 2004, p. 353; van der Meer and Paul, 2011, p. 105). Furthermore, while not directly focusing on the consequences of religion, cross-national research on citizen electoral behavior confirms that individual religiosity has a positive effect on people's support for governing parties, and that this effect remains highly statistically significant once we control for a host of other individual and contextual characteristics (e.g., Anderson, 2000, pp. 160-7). Hence, if more religious individuals believe that the world is just, then we can expect that the intensity of religious beliefs and practices contributes positively to people's support to their national government. Specifically, I hypothesize that:

Hypothesis 1. More religious people should express higher levels of satisfaction with their national governments than less religious individuals.

\section{Religious engagement and support for the principle of democratic accountability}

While religiosity can be expected to enhance people's satisfaction with their country's government, it should have a negative effect on citizens' attitudes and behavior related to democratic accountability. By shifting people's attention away from political actors and focusing on God as the ultimate causal agent, religion attenuates people's focus on politicians as an instrument in handling their country's economic or social problems. Besides, if the world is just and everyone will receive their just rewards (if not in this life then in the afterlife), then correcting injustices, including punishing governments for causing hardship, should be less relevant to believers than to non-believers. ${ }^{4}$

In addition to weaker motivations among believers to rely on political actors to correct all injustices, it may also be the case that adverse events are less intensely felt by believers than non-believers. Recall that religion provides its followers with cognitive tools and behavioral guidelines how to deal with the outside world, particularly in times adversity (e.g., Pargament, 1997, p. 3; Pargament and Hahn, 1986, p. 205). Hardship in itself is often seen by believers as part of the God's plan, as a test of their faith, and an opportunity for further spiritual growth (Kunst et al., 2000, p. 56; Overcash et al., 1996, p. 462; Szmajke, 1991, p. 41). Consistent

\footnotetext{
${ }^{3}$ For seminal studies on just world beliefs see Lerner (1977, 1980); for a useful literature overview in this area of research, see Furnham (2003).

${ }^{4}$ This perspective is consistent with previous research, which suggests that religiosity can serve as an alternative to political participation, thereby reducing people's motivations to engage politically (e.g., Barnes et al., 1979, pp. 118-9; see also Just et al., 2014, pp. 129-30). Part of the explanation for the negative relationship between religiosity and political action is that strong believers prefer devoting their time to religious practices rather than politics, except when they feel compelled to react to attacks on sacred values and anti-religious practices that interfere with their ability to live godly lives (e.g., Wald et al., 2005, p. 130). Others argue that it is precisely just world beliefs of religious individuals that provide them with a rationale for political inaction, because the belief system implies that people will receive their just rewards and therefore have no need for a political intervention (cf., Furnham, 2003, p. 810; Rubin and Peplau, 1975, p. 83).
} 
with this perspective, numerous studies in psychology demonstrate that believing is associated with better mental health and psychological well-being, as reflected in lower levels of depression, suicide, and life-dissatisfaction (e.g., Smith et al., 2003, p. 630; Ellison, 1991, p. 89; Ellison et al., 1989, p. 117). Moreover, the role of religion in alleviating the psychological costs of adversity has been used as a key explanation of believers' lower support for social welfare and redistribution compared to secular individuals (e.g., Scheve and Stasavage, 2006, p. 284). ${ }^{5}$ In short, because religious engagement reduces the psychological costs of adversity and because it deflects believers' attention away from political leaders as actors responsible for such adversity, I expect religious engagement to have a negative effect on people's motivations to support the principle of democratic accountability. Specifically,

Hypothesis 2. More religious individuals are less likely to support the idea that governing parties should be punished in elections when they have done a bad job while in office than less religious individuals or non-believers (support for democratic accountability in principle).

\section{Religious engagement and support for democratic accountability in practice}

In addition to understanding people's beliefs about the importance of holding governments accountable, I am also interested in the extent to which people enable democratic accountability in practice. One way to assess this is by examining the link between people's evaluations of government performance and satisfaction with their government. Since the economy is usually the most important issue for citizens in established democracies, democratic accountability features most prominently in the literature on economic voting. ${ }^{6}$ Countries are said to perform well with respect to democratic accountability when citizens express high levels of support for their government (in a form of electoral votes or government approval) in times of good economic performance, and low levels of support when the economy is doing badly.

However, the strength of the relationship between economic performance and government support has been found to vary greatly across both countries and individuals. Studies on individual barriers to democratic accountability emphasize the importance of people's cognitive abilities, such as political sophistication, but also people's varied motivations for responsibility attribution that are often rooted in individual partisan and ideological leanings (Anderson, 2007, p. 281). Building on this perspective, I posit that religious engagement influences people's motivations for responsibility attribution for economic outcomes. Specifically, since religion is closely linked with believing that the world is just and seeing God as the ultimate causal agent, strong believers are less likely to see political authorities as relevant actors in handling their country's economic problems, and are therefore less likely to punish governing parties for bad economic outcomes or reward them for good ones. If this theory is correct, then strong believers should be less likely to connect their evaluations of the macro-economy and satisfaction with their national government, leading to my next and final hypothesis:

Hypothesis 3. The positive relationship between economic evaluations and government satisfaction should be weaker among more religious individuals than less religious individuals or non-believers (support for democratic accountability in practice).

\section{Data and measures}

To test my hypotheses about the potential heterogeneity in people's democratic accountability attitudes due to religious engagement, I rely on the individual-level data from the European Social Survey (ESS) 2012-13 (round 6). This data project is known for its high standards of methodological rigor in survey design and cross-national data collection (Kittilson and caul, 2009, p. 882). Moreover, its sixth wave includes survey items measuring not only people's satisfaction with their national government and support for the principle of democratic accountability, but also various aspects of individual religious beliefs, including religiosity, attendance of religious services, and religious affiliation. The relevant survey items were available for seventeen established democracies: Belgium, Cyprus, Denmark, Finland, France, Germany, Great Britain, Iceland, Ireland, Israel, Italy, the Netherlands, Norway, Portugal, Spain, Sweden, and Switzerland.

\subsection{Dependent variables}

To capture people's attitudes towards the principle of democratic accountability, I used the following survey question: "Thinking generally rather than about [country], how important do you think it is for democracy in general that governing parties are punished in elections when they have done a bad job?" Response categories range from 0 to 10, with higher values indicating more support for the idea that governing parties should be punished at the ballot box for poor performance while in office.

Furthermore, I examine whether religion weakens the relationship between people's evaluations of the economy and their satisfaction with the incumbent government. The latter variable was measured using the following survey question: "Now thinking

\footnotetext{
${ }^{5}$ An additional perspective suggests that believers may be more forgiving and therefore more willing to overlook government failures in policy outcomes compared to non-believers. All major monotheistic religions, including Christianity, Islam, and Judaism, teach their followers the importance of forgiveness (McCullough and Worthington, 1999, pp. 1144-5). Whether more religious people are indeed more forgiving, however, remains a matter of debate. Existing research shows that while more religious people value forgiveness more than weak believers, the relationship between religious involvement and forgiveness in real life situations is tenuous at best (McCullough and Worthington, 1999, p. 1146).

${ }^{6}$ For a useful overview of this literature, see Anderson (2007).
} 
about the [country's] government, how satisfied are you with the way it is doing its job?" Responses to this question were recorded on a scale from 0 to 10 , with higher values indicating more government satisfaction.

\section{Independent variables}

I rely on two survey items to capture people's religiosity in both attitudinal and behavioral terms. First, respondents were asked, "Regardless of whether you belong to a particular religion, how religious would you say you are?" Responses to this question were coded on a scale from 0 to 10, with higher values indicating more intense religious beliefs. The second survey item asked respondents, "Apart from special occasions such as weddings and funerals, about how often do you attend religious services nowadays?" To facilitate the interpretation of the results, the original coding categories of this variable were reversed so that higher values indicate more frequent attendance of religious services; they range from 0 (never) to 6 (every day). Since the two survey items scale highly ${ }^{7}$ and produced nearly identical results with respect to all my hypotheses, the analyses reported below rely on a combined measure of individual religious engagement. To construct this measure, I first rescaled the variable measuring attendance of religious services so that it ranges from 0 to 10, and then calculated a mean value of individual responses to both survey items. The resulting index ranges from 0 to 10, with higher values indicating stronger individual religious engagement. In addition to reporting the estimates with the index of religious engagement in the analyses below, the online appendix provides the results of all my models using the original measures of religiosity and attendance of religious services.

Another independent variable of my main interest is people's evaluations of the macro-economy in their country. It was measured using the following survey question: "On the whole, how satisfied are you with the present state of the economy in [country]?" Response categories to this question range from 0 to 10 , with higher values indicating more positive economic evaluations.

\section{Control variables}

While the hypotheses of this study focus on the consequences of individual religious engagement, the models presented below also take into account people's belonging to different religious groups. Several survey items were used for this purpose: respondents were first asked if they consider themselves as belonging to any particular religion. If they said "yes", then they were requested to specify their religion. Using responses to these questions, I created dichotomous variables for Roman Catholics, Protestants, Eastern Orthodox, other Christian religions, Muslims, Jews, and other non-Christian religions, and used non-religious as a reference category for religious groups in my empirical estimations.

To ensure that the results with respect to government satisfaction are not driven by individual partisan leanings, I control for whether respondents feel close to a party in government. This measure is based on two survey items. Respondents were first asked whether there is a political party they feel closer to than all the other parties. If they answered positively, they were asked to identify that party. Individual responses to these questions were then matched with information from the European Journal of Political Research on government composition at the time of the survey to create a dichotomous variable, where 1 indicates that respondent feels close to a party in government, and 0 - otherwise.

To capture further micro-level heterogeneity, standard demographic variables - age, gender, marital status, and urban residence were included in the models. I also control for respondent's education, income, and professional skills, as individuals better situated in the labor market may be more satisfied with their country's government than those with little education, low income, and manual skills. To account for the consequences of social and political grievances, I rely on measures of perceived discrimination, being a crime victim, as well as the extremity of one's ideological views, while also taking into consideration respondent's left-right selfplacement. More detailed information on survey questions, coding, descriptive statistics for all variables, as well as robustness tests are available in the online appendix.

\section{Estimation and results}

To assess whether religious beliefs are linked to people's support for democratic accountability, the analyses proceed in several steps. First, I present the results using people's support for the principle of democratic accountability as a dependent variable. As a second step, I turn to respondents' satisfaction with their national government, and perform two types of analyses. First, I test whether individual religious engagement motivates people to express more positive opinions of their governments, while controlling for all other relevant factors, including feeling close to a party in government. Second, I examine whether more intense religious engagement weakens the expected positive relationship between economic evaluations and government satisfaction, and thereby undermines democratic accountability in practice.

Since my analyses rely on public opinion survey data collected in seventeen established democracies, the dataset has a multi-level structure (where one level, the individual, is nested within the other, the country). To avoid statistical problems associated with such a data structure, including clustering, non-constant variance, and incorrect (usually underestimated) standard errors (e.g., Steenbergen and Jones, 2002, pp. 219-20), I rely on multi-level models with random intercepts to account for cross-country heterogeneity in the levels of my dependent variables. The models of government satisfaction also include a random slope for the economic evaluations variable to account for cross-country variability in contextual characteristics that may shape people's ability to

\footnotetext{
${ }^{7}$ Cronbach's alpha for these two variables is .74, indicating that they may be combined into a single scale.
} 
Table 1

Religious engagement and support for the principle of democratic accountability in seventeen established democracies, 2012-13.

\begin{tabular}{|c|c|c|c|c|c|}
\hline \multirow[t]{2}{*}{ Variables } & \multirow{2}{*}{$\begin{array}{l}\text { Model I } \\
\text { Baseline } \\
\text { Model }\end{array}$} & \multirow{2}{*}{$\begin{array}{l}\text { Model II } \\
\text { With Feeling Close to a Party } \\
\text { in Government }\end{array}$} & \multirow{2}{*}{$\begin{array}{l}\text { Model III } \\
\text { No Israel }\end{array}$} & \multirow{2}{*}{$\begin{array}{l}\text { Model IV } \\
\text { Believers Only }\end{array}$} & \multirow{2}{*}{$\begin{array}{l}\text { Model V } \\
\text { With random slope of religious } \\
\text { engagement across religious groups }\end{array}$} \\
\hline & & & & & \\
\hline Religious engagement & $\begin{array}{l}-.033^{* * *} \\
(.006)\end{array}$ & $\begin{array}{l}-.033^{* * *} \\
(.006)\end{array}$ & $\begin{array}{l}-.025^{* * *} \\
(.006)\end{array}$ & $\begin{array}{l}-.024 * * * \\
(.007)\end{array}$ & $\begin{array}{l}-.030^{* *} \\
(.011)\end{array}$ \\
\hline Roman Catholic & $\begin{array}{l}.040 \\
(.039)\end{array}$ & $\begin{array}{l}.042 \\
(.039)\end{array}$ & $\begin{array}{l}.030 \\
(.039)\end{array}$ & $\begin{array}{l}-.133 \\
(.122)\end{array}$ & $\begin{array}{l}-.010 \\
(.077)\end{array}$ \\
\hline Protestant & $\begin{array}{l}.068 \\
(.037)\end{array}$ & $\begin{array}{l}.069 \\
(.037)\end{array}$ & $\begin{array}{l}.045 \\
(.037)\end{array}$ & $\begin{array}{l}-.124 \\
(.122)\end{array}$ & $\begin{array}{l}-.024 \\
(.079)\end{array}$ \\
\hline Eastern Orthodox & $\begin{array}{l}.352^{* *} \\
(.136)\end{array}$ & $\begin{array}{l}.348^{* * *} \\
(.136)\end{array}$ & $\begin{array}{l}.332^{*} \\
(.137)\end{array}$ & $\begin{array}{l}.182 \\
(.181)\end{array}$ & $\begin{array}{l}.175 \\
(.169)\end{array}$ \\
\hline Other Christian & $\begin{array}{l}.171 \\
(.149)\end{array}$ & $\begin{array}{l}.165 \\
(.118)\end{array}$ & $\begin{array}{l}.095 \\
(.119)\end{array}$ & $\begin{array}{l}-.020 \\
(.162)\end{array}$ & $\begin{array}{l}.128 \\
(.175)\end{array}$ \\
\hline Muslim & $\begin{array}{l}-.171 \\
(.088)\end{array}$ & $\begin{array}{l}-.172 \\
(.088)\end{array}$ & $\begin{array}{l}.073 \\
(.094)\end{array}$ & $\begin{array}{l}-.353^{*} \\
(.142)\end{array}$ & $\begin{array}{l}-.252 \\
(.142)\end{array}$ \\
\hline Jew & $\begin{array}{l}2.560^{* * *} \\
(.124)\end{array}$ & $\begin{array}{l}2.580^{* * * *} \\
(.124)\end{array}$ & $\begin{array}{l}-.069 \\
(.334)\end{array}$ & $\begin{array}{l}2.432^{* * *} \\
(.169)\end{array}$ & $\begin{array}{l}1.386^{* * *} \\
(.196)\end{array}$ \\
\hline Other non-Christian religion & $\begin{array}{l}.266^{*} \\
(.128)\end{array}$ & $\begin{array}{l}.262^{*} \\
(.128)\end{array}$ & $\begin{array}{l}.188 \\
(.127)\end{array}$ & - & $\begin{array}{l}.279 \\
(.156)\end{array}$ \\
\hline Left-right self-placement & $\begin{array}{l}-.004 \\
(.005)\end{array}$ & $\begin{array}{l}-.003 \\
(.005)\end{array}$ & $\begin{array}{l}-.010 \\
(.006)\end{array}$ & $\begin{array}{l}.001 \\
(.007)\end{array}$ & $\begin{array}{l}-.003 \\
(.005)\end{array}$ \\
\hline Left-right extremism & $\begin{array}{l}.030^{* * * *} \\
(.008)\end{array}$ & $\begin{array}{l}.034^{* * * *} \\
(.008)\end{array}$ & $\begin{array}{l}.039^{* * * *} \\
(.008)\end{array}$ & $\begin{array}{l}.025^{*} \\
(.010)\end{array}$ & $\begin{array}{l}.033^{* * * *} \\
(.008)\end{array}$ \\
\hline Discriminated against & $\begin{array}{l}.173^{* * * *} \\
(.046)\end{array}$ & $\begin{array}{l}.170^{* * * *} \\
(.046)\end{array}$ & $\begin{array}{l}.296^{* * * *} \\
(.049)\end{array}$ & $\begin{array}{l}.049 \\
(.059)\end{array}$ & $\begin{array}{l}.175^{* * * *} \\
(.046)\end{array}$ \\
\hline Crime victim & $\begin{array}{l}.055 \\
(.030)\end{array}$ & $\begin{array}{l}.055 \\
(.030)\end{array}$ & $\begin{array}{l}.064^{*} \\
(.030)\end{array}$ & $\begin{array}{l}.061 \\
(.039)\end{array}$ & $\begin{array}{l}.054 \\
(.030)\end{array}$ \\
\hline Education & $\begin{array}{l}.026^{* * *} \\
(.003)\end{array}$ & $\begin{array}{l}.026^{* * * *} \\
(.003)\end{array}$ & $\begin{array}{l}.027^{* * * *} \\
(.003)\end{array}$ & $\begin{array}{l}.032^{* * * *} \\
(.004)\end{array}$ & $\begin{array}{l}.025^{* * * *} \\
(.003)\end{array}$ \\
\hline Income & $\begin{array}{l}.018 \\
(.016)\end{array}$ & $\begin{array}{l}.020 \\
(.016)\end{array}$ & $\begin{array}{l}.003 \\
(.016)\end{array}$ & $\begin{array}{l}.033 \\
(.020)\end{array}$ & $\begin{array}{l}.019 \\
(.016)\end{array}$ \\
\hline Manual skills & $\begin{array}{l}-.005 \\
(.025)\end{array}$ & $\begin{array}{l}-.008 \\
(.025)\end{array}$ & $\begin{array}{l}-.016 \\
(.026)\end{array}$ & $\begin{array}{l}-.019 \\
(.033)\end{array}$ & $\begin{array}{l}-.010 \\
(.025)\end{array}$ \\
\hline Age & $\begin{array}{l}.060^{* * * *} \\
(.004)\end{array}$ & $\begin{array}{l}.060^{* * * *} \\
(.004)\end{array}$ & $\begin{array}{l}.059^{* * * *} \\
(.004)\end{array}$ & $\begin{array}{l}.053^{* * * *} \\
(005)\end{array}$ & $\begin{array}{l}.060^{* * * *} \\
(.004)\end{array}$ \\
\hline Age squared & $\begin{array}{l}-.000^{* * *} \\
(.000)\end{array}$ & $\begin{array}{l}-.000^{* * *} \\
(.000)\end{array}$ & $\begin{array}{l}-.000^{* * *} \\
(.000)\end{array}$ & $\begin{array}{l}-.000^{* * *} \\
(.000)\end{array}$ & $\begin{array}{l}-.000^{* * *} \\
(.000)\end{array}$ \\
\hline Male & $\begin{array}{l}-.165^{* * *} \\
(.023)\end{array}$ & $\begin{array}{l}-.166^{* * *} \\
(.023)\end{array}$ & $\begin{array}{l}-.176^{* * *} \\
(.024)\end{array}$ & $\begin{array}{l}-.170^{* * *} \\
(.030)\end{array}$ & $\begin{array}{l}-.170^{* * *} \\
(.024)\end{array}$ \\
\hline Married & $\begin{array}{l}.075^{* *} \\
(.026)\end{array}$ & $\begin{array}{l}.076^{* *} \\
(.026)\end{array}$ & $\begin{array}{l}.100^{* * * *} \\
(.027)\end{array}$ & $\begin{array}{l}.077^{*} \\
(.033)\end{array}$ & $\begin{array}{l}.076^{* *} \\
(.026)\end{array}$ \\
\hline Urban & $\begin{array}{l}.023^{*} \\
(.010)\end{array}$ & $\begin{array}{l}.023^{*} \\
(.010)\end{array}$ & $\begin{array}{l}.008 \\
(.010)\end{array}$ & $\begin{array}{l}.041^{* *} \\
(.013)\end{array}$ & $\begin{array}{l}.020 \\
(.010)\end{array}$ \\
\hline Feeling close to a governing party & - & $\begin{array}{l}-.100^{* * *} \\
(.028)\end{array}$ & $\begin{array}{l}-.115^{* * *} \\
(.029)\end{array}$ & $\begin{array}{l}-.086^{*} \\
(.035)\end{array}$ & $\begin{array}{l}-.095^{* * *} \\
(.028)\end{array}$ \\
\hline Constant & $\begin{array}{l}6.217^{* * *} \\
(.201)\end{array}$ & $\begin{array}{l}6.210^{* * *} \\
(.201)\end{array}$ & $\begin{array}{l}6.422^{* * * *} \\
(.146)\end{array}$ & $\begin{array}{l}6.443^{* * *} \\
(.248)\end{array}$ & $\begin{array}{l}6.310^{* * *} \\
(.167)\end{array}$ \\
\hline Variance Components & & & & & \\
\hline Random intercept: country & $\begin{array}{l}.495 \\
(.173)\end{array}$ & $\begin{array}{l}.496 \\
(.173)\end{array}$ & $\begin{array}{l}.154 \\
(.057)\end{array}$ & $\begin{array}{l}.503 \\
(.176)\end{array}$ & $\begin{array}{l}.268 \\
(.102)\end{array}$ \\
\hline Random intercept: religious groups & - & - & - & - & $\begin{array}{l}.011 \\
(.021)\end{array}$ \\
\hline $\begin{array}{l}\text { Radom slope (across religious groups): } \\
\text { religious engagement }\end{array}$ & - & - & - & - & $\begin{array}{l}.005 \\
(.002)\end{array}$ \\
\hline Residuals & $\begin{array}{l}3.670 \\
(.031)\end{array}$ & $\begin{array}{l}3.668 \\
(.031)\end{array}$ & $\begin{array}{l}3.528 \\
(.031)\end{array}$ & $\begin{array}{l}3.569 \\
(.040)\end{array}$ & $\begin{array}{l}3.643 \\
(.031)\end{array}$ \\
\hline Number of observations & 27,463 & 27,463 & 25,419 & 16,238 & 27,463 \\
\hline Wald $X^{2}$ (df) & $\begin{array}{l}1650.84 \\
(20)^{* * * *}\end{array}$ & $\begin{array}{l}1664.54 \\
(21)^{* * *}\end{array}$ & $\begin{array}{l}963.87 \\
(21)^{* * * *}\end{array}$ & $\begin{array}{l}1217.34 \\
(20)^{* * *}\end{array}$ & $\begin{array}{l}1000.04 \\
(21)^{* * *}\end{array}$ \\
\hline
\end{tabular}

Note: $* \mathrm{p}<.05, * * \mathrm{p}<.01, * * * \mathrm{p}<.001$ (two-tailed); the reference category for religious groups in Models I, II, III, and V is respondents who are not affiliated with any religion, while in Model IV (where non-believers are excluded) the reference category is other non-Christian religions.

connect their economic evaluations to their government satisfaction. This means, for example, that in countries where the clarity of responsibility for economic outcomes is high, the inclusion of a random slope allows economic evaluations to have a more powerful effect on government satisfaction compared to countries where the clarity of responsibility is more diffuse.

Table 1 reports the results using individual support for the idea that parties in government should be punished in elections when they have done a bad job while in office as a dependent variable. The baseline results in Model I reveal a negative and statistically 
significant coefficient of the religious engagement variable. Hence, in line with my Hypothesis 2, people's support for the principle of democratic accountability weakens with the intensity of their religious beliefs and practices. Model II tests the robustness of this finding by additionally controlling for whether respondent feels close to a party in government. The results do not change as a consequence of this powerful control: while individuals feeling close to a party in government attach less importance to holding governments accountable, the estimate for religious engagement remains essentially unchanged. Model III relies on the same variables as Model II but excludes Israel - a country that is unusual in terms of its religious composition and the intensity of ethnoreligious conflict compared to other established democracies in this study. The results reveal that although the coefficient of religious engagement is somewhat reduced in substantive terms, it remains in the expected direction and highly statistically significant. Model IV further tests the robustness of my findings by focusing on a more restricted sample of respondents who belong to a religious group or denomination and excluding non-believers. ${ }^{8}$ The results remain the same. Finally, Model V uses random slope of religious engagement across religious groups and denominations within countries. This model specification allows for the possibility that religious engagement might have a stronger impact on people's support for democratic accountability in some faiths than in others (for example, as a consequence of differences in religious doctrines or political mobilization efforts by religious leaders). The results of this model reveal that, while there is indeed some variation in the slope of religious engagement across faiths, the coefficient of religious engagement remains negative and highly statistically significant.

Additional analyses with interactions between religious engagement and each of the religious groups or denominations (not reported here but available upon request) show that interactions for all religious groups, except Protestants, were statistically insignificant, while the additive term for religious engagement remained unchanged. In the case of Protestants, more intense religious engagement does not reduce their support for the principle of democratic accountability. Explaining these cross-faith differences goes beyond the scope of this paper but could be a fruitful venue for future research.

Among control variables, there are some notable patterns as well. Perhaps not surprisingly, more educated, married, and older individuals express more support for the idea that parties in government should be punished in elections for poor performance while in office than less educated, single, or younger respondents, although this support dips slightly at a particularly old age. Interestingly, women attach more importance to democratic accountability than men, while income and manual skills have no statistically significant effects. Moreover, neither right-wing nor left-wing orientations are associated with the dependent variable. However, holding extreme ideological views encourages people to express more support for the idea that governing parties should be punished in elections when they have done a bad job.

How much does religious engagement matter in substantive terms and how does this effect compare to the impact of other determinants of support for democratic accountability? Calculating marginal effects reveals that, as we move from the minimum to the maximum value of religious engagement (on a scale from 0 to 10) while holding dichotomous variables at their medians and other variables at their means, the score of individual support for democratic accountability declines from 8.322 to 7.995 (a difference of -.327 ). Moving from -1 to +1 standard deviation from the mean of religious engagement results in a drop of .165 points. This effect is similar or even larger than the substantive impact of some traditional predictors of my dependent variable. For example, the marginal effect of feeling close to a governing party on support for democratic accountability is -.100 , while the marginal effect of being discriminated against is $.170 .{ }^{9}$ Taken together, these results support my Hypothesis 2 that individual commitment to the principle of democratic accountability declines with more intense religious engagement.

While the analyses presented above focus on people's support for democratic accountability in principle, an equally important issue is the extent to which people hold governments accountable in practice. Table 2 reports the results of my models testing the direct and moderating effects of religious engagement on people's satisfaction with their country's national government. As before, I first provide my baseline results (Model I), followed by a model using an important additional control - feeling close to a party in government (Model II). Model III checks whether the results remain the same when Israel is dropped from the sample, while Model IV focuses exclusively on individuals who reported belonging to a religious group or denomination while excluding non-believers. Finally, Model V offers an additional robustness test by allowing the slope of religious engagement to vary across different religious groups and denominations.

The results confirm that religious engagement has a consistent positive and statistically significant effect on government satisfaction. ${ }^{10}$ Hence, in line with my expectation formulated in Hypothesis 1, more religious individuals express more positive opinions about their national governments. Interestingly, these results remain largely unchanged when people's partisan leanings are accounted for, that is, when controlling for whether a respondent feels close to a party in government or not (Model II). Similarly, dropping Israel from the sample (Model III), excluding respondents who do not belong to any religion (Model IV), or using a random slope of religious engagement across religious groups or denominations (Model V) have no considerable consequences for my finding that more religiously engaged individuals express more satisfaction with their national governments.

The results also show that the interaction between religious engagement and economic evaluations is negative and highly statistically significant. This suggests that, when expressing satisfaction with their country's government, more religious individuals rely

\footnotetext{
${ }^{8}$ Since respondents without any religious affiliation are excluded from the sample, the reference category for religious groups in this model is other non-Christian religions.

${ }^{9}$ As before, in calculating these effects, dichotomous variables were held at their medians and other variables at their means.

${ }^{10}$ Since all models in Table 2 include an interaction term with economic evaluations, the coefficient for the additive term of religious engagement indicates its effect when the value of economic evaluations is set at zero, that is, at the level of extreme dissatisfaction with the economy. However, excluding the interaction term from the models in Table 2 shows that the coefficient of religious engagement remains positive and highly statistically significant (the results are available from the author upon request).
} 
Table 2

Support for democratic accountability in practice: The moderating effects of religious engagement between economic evaluations and government satisfaction in seventeen established democracies, 2012-13.

\begin{tabular}{|c|c|c|c|c|c|}
\hline \multirow[t]{2}{*}{ Variables } & \multirow{2}{*}{$\begin{array}{l}\text { Model I } \\
\text { Baseline Model }\end{array}$} & \multirow{2}{*}{$\begin{array}{l}\text { Model II } \\
\text { With Feeling } \\
\text { Close to a Party } \\
\text { in Government }\end{array}$} & \multirow{2}{*}{$\begin{array}{l}\text { Model III } \\
\text { No Israel }\end{array}$} & \multirow{2}{*}{$\begin{array}{l}\text { Model IV } \\
\text { Believers } \\
\text { Only }\end{array}$} & \multirow{2}{*}{$\begin{array}{l}\text { Model IV } \\
\text { With random slope } \\
\text { of religious } \\
\text { engagement across } \\
\text { religious groups }\end{array}$} \\
\hline & & & & & \\
\hline Religious engagement & $\begin{array}{l}.102 * * * \\
(.010)\end{array}$ & $\begin{array}{l}.093^{* * *} \\
(.009)\end{array}$ & $\begin{array}{l}.087 * * * \\
(.010)\end{array}$ & $\begin{array}{l}.097 * * * \\
(.012)\end{array}$ & $\begin{array}{l}.075 * * * \\
(.012)\end{array}$ \\
\hline Satisfaction with economy & $\begin{array}{l}.611 * * * \\
(.023)\end{array}$ & $\begin{array}{l}.585^{* * *} \\
(.022)\end{array}$ & $\begin{array}{l}.589 * * * \\
(.023)\end{array}$ & $\begin{array}{l}.602^{* * *} \\
(.025)\end{array}$ & $\begin{array}{l}.581 * * * \\
(.022)\end{array}$ \\
\hline $\begin{array}{l}\text { Religious engagement*Satisfaction with } \\
\text { economy }\end{array}$ & $\begin{array}{l}-.006 * * * \\
(.002)\end{array}$ & $\begin{array}{l}-.005^{* * * *} \\
(.002)\end{array}$ & $\begin{array}{l}-.006 * * * \\
(.002)\end{array}$ & $\begin{array}{l}-.008 * * * \\
(.002)\end{array}$ & $\begin{array}{l}-.004 * \\
(.002)\end{array}$ \\
\hline Roman Catholic & $\begin{array}{l}-.014 \\
(.036)\end{array}$ & $\begin{array}{l}-.030 \\
(.035)\end{array}$ & $\begin{array}{l}.001 \\
(.036)\end{array}$ & $\begin{array}{l}-.125 \\
(.116)\end{array}$ & $\begin{array}{l}.025 \\
(.063)\end{array}$ \\
\hline Protestant & $\begin{array}{l}.013 \\
(.035)\end{array}$ & $\begin{array}{l}-.005 \\
(.034)\end{array}$ & $\begin{array}{l}.021 \\
(.034)\end{array}$ & $\begin{array}{l}-.070 \\
(.116)\end{array}$ & $\begin{array}{l}.103 \\
(.065)\end{array}$ \\
\hline Eastern Orthodox & $\begin{array}{l}.160 \\
(.127)\end{array}$ & $\begin{array}{l}.209 \\
(.123)\end{array}$ & $\begin{array}{l}.337^{* *} \\
(.129)\end{array}$ & $\begin{array}{l}.051 \\
(.171)\end{array}$ & $\begin{array}{l}.279 \\
(.144)\end{array}$ \\
\hline Other Christian & $\begin{array}{l}-.130 \\
(.109)\end{array}$ & $\begin{array}{l}-.073 \\
(.106)\end{array}$ & $\begin{array}{l}-.045 \\
(.107)\end{array}$ & $\begin{array}{l}-.127 \\
(.152)\end{array}$ & $\begin{array}{l}.015 \\
(.141)\end{array}$ \\
\hline Muslim & $\begin{array}{l}.325^{* * *} \\
(.082)\end{array}$ & $\begin{array}{l}.362^{* * *} \\
(.079)\end{array}$ & $\begin{array}{l}.480 * * * \\
(.085)\end{array}$ & $\begin{array}{l}.298^{*} \\
(.135)\end{array}$ & $\begin{array}{l}.590 * * * \\
(.115)\end{array}$ \\
\hline Jew & $\begin{array}{l}.519^{* * *} \\
(.115)\end{array}$ & $\begin{array}{l}.324^{* *} \\
(.111)\end{array}$ & $\begin{array}{l}-.240 \\
(.297)\end{array}$ & $\begin{array}{l}.263 \\
(.159)\end{array}$ & $\begin{array}{l}.010 \\
(.163)\end{array}$ \\
\hline Other religion & $\begin{array}{l}.031 \\
(.122)\end{array}$ & $\begin{array}{l}.076 \\
(.118)\end{array}$ & $\begin{array}{l}.104 \\
(.118)\end{array}$ & - & $\begin{array}{l}.148 \\
(.135)\end{array}$ \\
\hline Left-right self-placement & $\begin{array}{l}.025^{* * *} \\
(.005)\end{array}$ & $\begin{array}{l}.021^{* * *} \\
(.005)\end{array}$ & $\begin{array}{l}.000 \\
(.005)\end{array}$ & $\begin{array}{l}.028^{* * *} \\
(.007)\end{array}$ & $\begin{array}{l}.018^{* * *} \\
(.005)\end{array}$ \\
\hline Left-right extremism & $\begin{array}{l}-.030 * * * \\
(.007)\end{array}$ & $\begin{array}{l}-.067^{* * * *} \\
(.007)\end{array}$ & $\begin{array}{l}-.060^{* * *} \\
(.007)\end{array}$ & $\begin{array}{l}-.066^{* * *} \\
(.010)\end{array}$ & $\begin{array}{l}-.067^{* * *} \\
(.007)\end{array}$ \\
\hline Discriminated against & $\begin{array}{l}-.446^{* * *} \\
(.043)\end{array}$ & $\begin{array}{l}-.432 * * * \\
(.042)\end{array}$ & $\begin{array}{l}-.389 * * * \\
(.045)\end{array}$ & $\begin{array}{l}-.446^{* * *} \\
(.056)\end{array}$ & $\begin{array}{l}-.431^{* * *} \\
(.042)\end{array}$ \\
\hline Crime victim & $\begin{array}{l}-.069 * \\
(.028)\end{array}$ & $\begin{array}{l}-.079 * * \\
(.027)\end{array}$ & $\begin{array}{l}-.081^{* *} \\
(.027)\end{array}$ & $\begin{array}{l}-.054 \\
(.037)\end{array}$ & $\begin{array}{l}-.077 * * \\
(.027)\end{array}$ \\
\hline Education & $\begin{array}{l}.005 \\
(.003)\end{array}$ & $\begin{array}{l}.000 \\
(.003)\end{array}$ & $\begin{array}{l}.002 \\
(.003)\end{array}$ & $\begin{array}{l}-.006 \\
(.004)\end{array}$ & $\begin{array}{l}.001 \\
(.003)\end{array}$ \\
\hline Income & $\begin{array}{l}.103^{* * *} \\
(.015)\end{array}$ & $\begin{array}{l}.090 * * * \\
(.014)\end{array}$ & $\begin{array}{l}.096 * * * \\
(.015)\end{array}$ & $\begin{array}{l}.091 * * * \\
(.019)\end{array}$ & $\begin{array}{l}.094 * * * \\
(.014)\end{array}$ \\
\hline Manual skills & $\begin{array}{l}-.108^{* * *} \\
(.024)\end{array}$ & $\begin{array}{l}-.082^{* * *} \\
(.023)\end{array}$ & $\begin{array}{l}-.094 * * * \\
(.024)\end{array}$ & $\begin{array}{l}-.072 * \\
(.031)\end{array}$ & $\begin{array}{l}-.083^{* * *} \\
(.023)\end{array}$ \\
\hline Male & $\begin{array}{l}.067^{* *} \\
(.022)\end{array}$ & $\begin{array}{l}.076 * * * \\
(.021)\end{array}$ & $\begin{array}{l}.077 * * * \\
(.022)\end{array}$ & $\begin{array}{l}.039 \\
(.028)\end{array}$ & $\begin{array}{l}.082^{* * *} \\
(.021)\end{array}$ \\
\hline Age & $\begin{array}{l}-.020 * * * \\
(.003)\end{array}$ & $\begin{array}{l}-.023^{* * *} \\
(.003)\end{array}$ & $\begin{array}{l}-.022^{* * *} \\
(.003)\end{array}$ & $\begin{array}{l}-.020 * * * \\
(.004)\end{array}$ & $\begin{array}{l}-.023^{* * *} \\
(.003)\end{array}$ \\
\hline Age squared & $\begin{array}{l}.000 * * * \\
(.000)\end{array}$ & $\begin{array}{l}.000^{* * *} \\
(.000)\end{array}$ & $\begin{array}{l}.000 * * * \\
(.000)\end{array}$ & $\begin{array}{l}.000 * * * \\
(.000)\end{array}$ & $\begin{array}{l}.000 * * * \\
(.000)\end{array}$ \\
\hline Married & $\begin{array}{l}.032 \\
(.025)\end{array}$ & $\begin{array}{l}.021 \\
(.024)\end{array}$ & $\begin{array}{l}.035 \\
(.024)\end{array}$ & $\begin{array}{l}.008 \\
(.032)\end{array}$ & $\begin{array}{l}.017 \\
(.024)\end{array}$ \\
\hline Urban & $\begin{array}{l}.029 * * \\
(.009)\end{array}$ & $\begin{array}{l}.024 * * \\
(.009)\end{array}$ & $\begin{array}{l}.019 * \\
(.009)\end{array}$ & $\begin{array}{l}.017 \\
(.012)\end{array}$ & $\begin{array}{l}.019 * \\
(.009)\end{array}$ \\
\hline Feeling close to a governing party & - & $\begin{array}{l}1.065^{* * *} \\
(.026)\end{array}$ & $\begin{array}{l}1.081^{* * *} \\
(.026)\end{array}$ & $\begin{array}{l}1.092^{* * *} \\
(.034)\end{array}$ & $\begin{array}{l}1.046^{* * * *} \\
(.026)\end{array}$ \\
\hline Constant & $\begin{array}{l}1.485^{* * *} \\
(.174)\end{array}$ & $\begin{array}{l}1.649^{* * *} \\
(.160)\end{array}$ & $\begin{array}{l}1.709^{* * *} \\
(.169)\end{array}$ & $\begin{array}{l}1.688^{* * *} \\
(.220)\end{array}$ & $\begin{array}{l}1.682^{* * * *} \\
(.160)\end{array}$ \\
\hline Variance Components & & & & & \\
\hline Random intercept: country & $\begin{array}{l}.324 \\
(.119)\end{array}$ & $\begin{array}{l}.258 \\
(.096)\end{array}$ & $\begin{array}{l}.278 \\
(.105)\end{array}$ & $\begin{array}{l}.268 \\
(.105)\end{array}$ & $\begin{array}{l}.244 \\
(.093)\end{array}$ \\
\hline $\begin{array}{l}\text { Random slope (across countries): satisfaction } \\
\text { with economy }\end{array}$ & $\begin{array}{l}.007 \\
(.003)\end{array}$ & $\begin{array}{l}.007 \\
(.002)\end{array}$ & $\begin{array}{l}.008 \\
(.003)\end{array}$ & $\begin{array}{l}.007 \\
(.003)\end{array}$ & $\begin{array}{l}.007 \\
(.002)\end{array}$ \\
\hline Random intercept: religious groups & - & - & - & - & $\begin{array}{l}.006 \\
(.007)\end{array}$ \\
\hline $\begin{array}{l}\text { Random slope (across religious groups): } \\
\text { religious engagement }\end{array}$ & - & - & - & - & $\begin{array}{l}.002 \\
(.001)\end{array}$ \\
\hline Residuals & $\begin{array}{l}3.235 \\
(.028)\end{array}$ & $\begin{array}{l}3.044 \\
(.026)\end{array}$ & $\begin{array}{l}2.971 \\
(.026)\end{array}$ & $\begin{array}{l}3.190 \\
(.035)\end{array}$ & $\begin{array}{l}3.017 \\
(.026)\end{array}$ \\
\hline Number of observations & 27,592 & 27,592 & 25,500 & 16,350 & 27,592 \\
\hline
\end{tabular}


Table 2 (continued)

\begin{tabular}{|c|c|c|c|c|c|}
\hline \multirow[t]{2}{*}{ Variables } & Model I & Model II & Model III & Model IV & Model IV \\
\hline & Baseline Model & $\begin{array}{l}\text { With Feeling } \\
\text { Close to a Party } \\
\text { in Government }\end{array}$ & No Israel & $\begin{array}{l}\text { Believers } \\
\text { Only }\end{array}$ & $\begin{array}{l}\text { With random slope } \\
\text { of religious } \\
\text { engagement across } \\
\text { religious groups }\end{array}$ \\
\hline Wald $X^{2}$ (df) & $\begin{array}{l}1528.36 \\
(22)^{* * *}\end{array}$ & $\begin{array}{l}3376.06 \\
(23)^{* * *}\end{array}$ & $\begin{array}{l}3053.45 \\
(23)^{* * *}\end{array}$ & $\begin{array}{l}2210.37 \\
(22)^{* * * *}\end{array}$ & $\begin{array}{l}3003.66 \\
(23)^{* * *}\end{array}$ \\
\hline
\end{tabular}

Note: $* \mathrm{p}<.05, * * \mathrm{p}<.01, * * * \mathrm{p}<.001$ (two-tailed); the reference category for religious groups in Models I, II, III, and V is respondents who are not affiliated with any religion, while in Model IV (where non-believers are excluded) the reference category is other non-Christian religions.

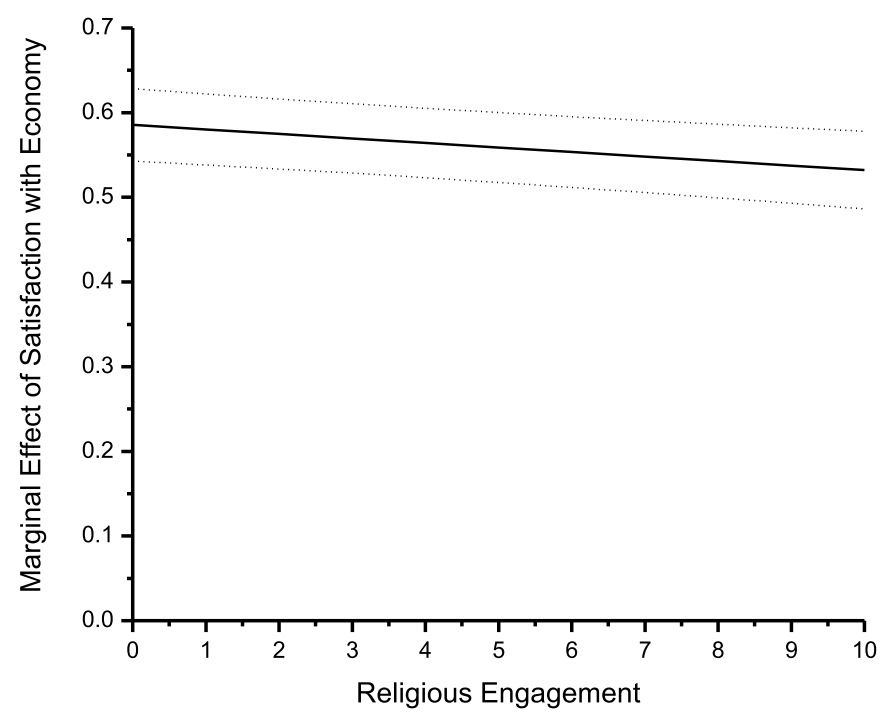

Fig. 1. Marginal effects of one-unit change in satisfaction with economy on government satisfaction at various levels of religious engagement in seventeen established democracies, 2012-13.

on economic evaluations to a lesser extent than weak believers or non-believers. Controlling for closeness to a party in government does not change these findings in any significant way, confirming my expectations in Hypothesis 3 that religious engagement plays a moderating role in the relationship between economic evaluations and government satisfaction. Analyses reported in Models III-V reveal that these results are robust to different model and sample specifications described above.

Additional robustness tests (reported in the online appendix) indicate that disaggregating the index of religious engagement into religiosity and attendance of religious services produces almost identical results as with the combined index of religious engagement. Furthermore, following Ben-Nun Bloom and Gizem (2012a, p. 397), I re-estimated my models with controls for traditional and survival values but found no considerable changes in my key results. The estimates remain the same also when additionally controlling for the presence of religious parties in national parliament, the strength of religious parties measured using seat shares in their country's national parliament, and the presence of religious parties in government at the time of the survey. Finally, since my analyses are based on cross-national data, I tested the robustness of my findings by re-running the models while excluding one country at the time. The results of this "jackknife" technique demonstrate that my key findings do not change appreciably, and my inferences remain the same.

To assess how much religious engagement contributes to people's satisfaction with their country's government in substantive terms, Figs. 1 and 2 plot the marginal effects of my key variables of interest using the results of my fully specified model (Model II) in Table 2. Following recommendations for testing conditional hypotheses in recent research (Berry et al., 2012), marginal effects (with 95\% confidence intervals) are reported using two figures: the first figure shows the marginal effects of economic evaluations on government support at various levels of religious engagement, while the second figure demonstrates the marginal effects of religious engagement on government satisfaction, as we move from the most negative to the most positive individual assessment of the state of the economy.

The results reveal that the key variables of interest indeed have the expected effects on people's satisfaction with their country's national government. Specifically, Fig. 1 indicates that the marginal effect of one-unit change in economic evaluations (on a scale 


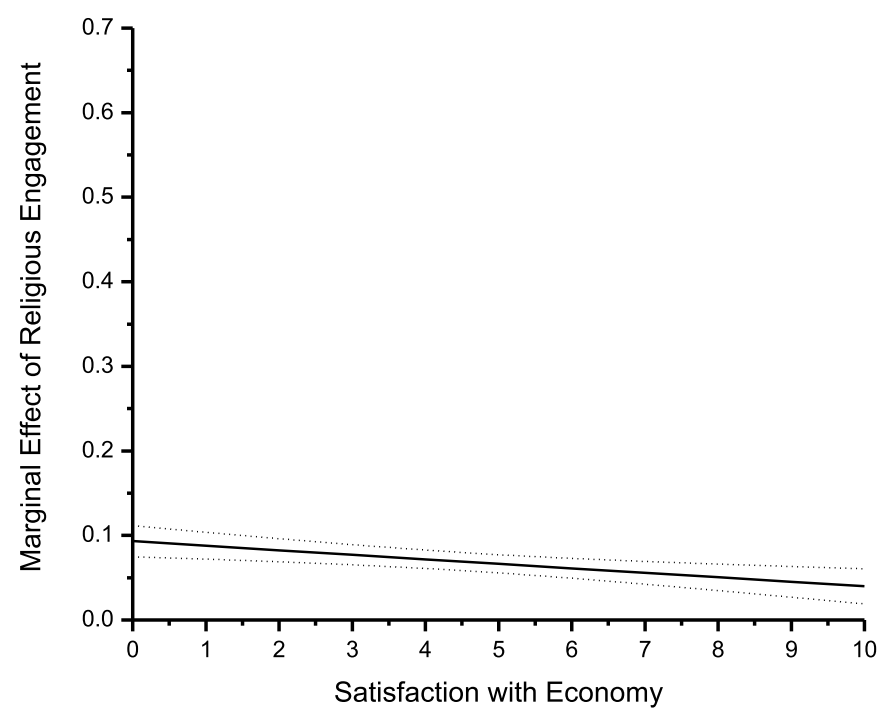

Fig. 2. Marginal effect of one-unit change in religious engagement on government satisfaction at various levels of satisfaction with economy in seventeen established democracies, 2012-13.

from 0 to 10) on government satisfaction declines from .585 to .532, as we move from the lowest to the highest score of individual religious engagement (a difference of .053 points). The results also show that this marginal effect remains positive and statistically distinguishable from zero at all values of religious engagement. This means that the intensity of one's religious beliefs and practices does not neutralize the consequences of economic evaluations for government support entirely: more religious individuals do consider the state of the economy in expressing satisfaction with their country's government. However, as expected, they do so to a lesser extent than weak believers or secular individuals.

Fig. 2 provides additional support for the conditional hypothesis. Specifically, it shows that the marginal effect of one-unit change in religious engagement (on a scale from 0 to 10) on government support is reduced from .093 to .040, as we shift from the lowest to the highest level of satisfaction with the state of the economy in one's country. This means that the marginal effect of change from the lowest to the highest level of religious engagement on government support declines from .930 to .400, as we move from the most negative to the most positive economic evaluations. Moreover, the marginal effect of religious engagement remains statistically distinguishable from 0 at all values of economic evaluations.

The marginal effect of religious engagement is substantial compared to other commonly used predictors of government satisfaction. For example, as we move from the most leftist to the most rightist position on a left-right self-placement scale (while holding dichotomous variables at their medians and other variables at their means), government satisfaction increases by .212 points. Similarly, moving from the minimum to the maximum value of income scale raises government satisfaction from 4.030 to 4.301 (a difference of .271), while the marginal effect of discrimination experiences on government satisfaction is -.432 . Economic evaluations, however, remain the most powerful determinant of government satisfaction: since, as reported above, one-unit change in economic evaluations (on a scale from 0 to 10) generates a .532 increase in government satisfaction among strong believers and .585 increase among non-believers or secular individuals, moving from the lowest to the highest value of satisfaction with the economy would produce an effect that is ten times larger.

Taken together, these results confirm that both religious engagement and economic evaluations contribute positively to government satisfaction, although economic evaluations do so to a considerably greater extent than religious engagement. At the same time, the substantive impact of religious engagement is similar to or even higher than the effects of some commonly used predictors of government satisfaction, such as income or discrimination experiences. Finally, the results show that evaluations of policy outcomes and religious engagement should not be considered in isolation, as they clearly moderate each other's effect on citizens' opinions about their national governments. Since strong believers are less likely to employ evaluations of policy outcomes in judging their country's national governments than weak believers or non-believers, the results support my expectation that religious engagement weakens democratic accountability in practice.

\section{Conclusions}

This paper examines the role of religion in shaping public support for government accountability in contemporary democracies. It focuses on a micro-level explanation, arguing that religious engagement - in a form of individual religiosity and attendance of religious services - is associated with lower levels of public support for democratic accountability. Specifically, accounting for people's affiliation with different religious groups or denominations, strong believers are less likely to express commitment to the principle of democratic accountability than weak believers or non-believers. Moreover, more intense religious engagement weakens the connection between people's evaluations of policy outcomes and government satisfaction. The analyses of individual-level data, 
collected as part of the European Social Survey 2012-13 (round 6) in seventeen established democracies confirm these expectations. In contrast to a common assumption that believers are more judgmental, I find that religious engagement undermines people's support for democratic accountability, while at the same time contributing positively to their satisfaction with their country's government.

I posit, although cannot test directly, that the effects uncovered in this paper are rooted in the just world beliefs of religious individuals. Previous research shows that more intense religious beliefs and practices are closely linked to believing that the world is just. This perspective enables us to understand why, in comparison to weak believers or secular individuals, strong believers are more satisfied with their national government. Since just world beliefs encourage believers to trust that people get what they deserve and deserve what they get, they are more likely to see those in power as deserving their positions. Consequently, strong believers are more satisfied with their country's national government than weak believers or non-believers. At the same time, however, believing that the world is just and considering God as the ultimate causal agent weakens the relevance of political authority to believers in handling their country's problems. Not surprisingly, then, more devout individuals are less likely to support democratic accountability, both in principle and in practice.

These findings have important implications for public and scholarly debates on the relationship between religion and democratic governance. Previous studies questioned compatibility of religious beliefs and support for democratic values by pointing out that religion deals in absolute truths of divine origin, leaving little room for compromise, tolerance, and deliberation that are at the core of democratic governance. The results presented here add to this discussion by showing that religion - in the form of more intense religious beliefs and practices - also weakens people's attitudes and behavior necessary for holding governments accountable for their performance while in office.

Interestingly, whereas some scholars find that attendance of religious services contributes positively to people's support for democratic governance, while religiosity undermines it (e.g., Ben-Nun Bloom and Gizem, 2012b, p. 268), this study reveals no evidence of such differential effects with respect to democratic accountability. Instead, when using a disaggregated measure of religious engagement (the results reported in the online appendix), I find that both attendance of religious services and religiosity are negatively related to people's support for democratic accountability. Moreover, the results are even more statistically significant for attendance of religious services than they are for individual religiosity. Hence, the social aspect of religious engagement does not always contribute positively to democratic governance. While exposure to religious institutions may increase political interest, and teach people civic skills that benefit democracy, it does not motivate people to adopt the kind of attitudes and behavior that enhance democratic accountability.

These findings suggest that governments in more religious societies may have more room to maneuver without being punished at the ballot box for poor governance. At the same time, they may also be less likely to be rewarded for good policy outcomes. The latter may not be of particular concern to governments in religious societies because, as the results of this study show, religious engagement has a powerful positive effect on government satisfaction regardless of which party is in power. Viewed from this perspective, religion has a capacity to serve as a basis for political stability and legitimacy. Yet, this stability may not emerge in countries that need it most. Recall that the analyses presented here focus on established democracies. It is possible that the effects of religion uncovered in this study are due to the fact that there is less at stake in fully-fledged democracies as opposed to other political regimes, enabling more devout individuals to focus more on their faith and less on political life. This may not be the case in newer or partial democracies, particularly where religion constitutes a dividing line among electoral contenders. Future studies would benefit from further inquiries into how political context influences the relationship between religion and public support for various aspects of democratic governance.

\section{Appendix A. Supplementary data}

Supplementary data related to this article can be found at doi: http://dx.doi.org/10.1016/j.ssresearch.2018.06.002.

\section{References}

Aarts, Olav, Need, Ariana, Te Grotenhuis, Manfred, Graaf, Nan Dirk De, 2008. Does belonging accompany Believing? Correlations and trends in western Europe and north America between 1981 and 2000. Rev. Relig. Res. 50 (1), 16-34.

Altemeyer, Bob, 1988. Enemies of Freedom: Understanding Right-Wing Authoritarianism. Jossey-Bass Publishers, San Francisco.

Anderson, Christopher J., 2000. Economic voting and political context: a comparative perspective. Elect. Stud. 19 (2-3), 151-170.

Anderson, Christopher J., 2007. The end of economic voting? Contingency dilemmas and the limits of democratic accountability. Annu. Rev. Polit. Sci. 10, 271-296. Anderson, Christopher J., Singer, Matthew, 2008. The sensitive left and the impervious rigth: multilevel models and the politics of inequality, ideology, and legitimacy in Europe. Comp. Polit. Stud. 41 (4/5), 564-599.

Barnes, Samuel H., Kaase, Max, with Klaus, R., Barbara Farah, Allerbeck, Heunks, Felix, Inglehart, Ronald, Kent Jennings, M., Klingemann, Hans D., Marsh, Alan, Rosenmayr, Leopold, 1979. Political Action: Mass Participation in Five Western Democracies. Sage Publications, Beverly Hills.

Bellin, Eva, 2008. Faith in politics: new trends in the study of religion and politics. World Polit. 60 (2), 315-347.

Ben-Nun Bloom, Pazit, Gizem, Arikan, 2012a. Religion and support for democracy: a cross-national test of the mediating mechanisms. Br. J. Polit. Sci. 43 (2), 375-397.

Ben-Nun Bloom, Pazit, Gizem, Arikan, 2012b. A two-edged sword: the differential effect of religious belief and religious social context on attitudes toward democracy. Polit. Behav. 34 (2), 249-276.

Berry, William D., Golder, Matt, Milton, Daniel, 2012. Improving tests of theories positing interaction. J. Polit. 74 (3), $653-671$.

Botterman, Sarah, Hooghe, Marc, 2012. Religion and voting behaviour in Belgium: an analysis of the relation between religious beliefs and christian democratic voting. Acta Politic. 47 (1), 1-17.

Dahl, Robert A., 1971. Polyarchy: Participation and Opposition. Yale University Press, New Haven.

Eisenstein, Marie A., 2006. Rethinking the relationship between religion and political tolerance in the US. Polit. Behav. 28 (4), $327-348$.

Elff, Martin, Roßteutscher, Sigrid, 2011. Stability or decline? Class, religion and the vote in Germany. Ger. Polit. 20 (1), $107-127$.

Ellison, Christopher G., 1991. Religious involvement and subjective well-being. J. Health Soc. Behav. 32 (1), 80-99. 
Ellison, Christopher G., Gray, David A., Glass, Thomas A., 1989. Does religious commitment contribute to individual life satisfaction? Soc. Forces 68 (1), 100-123. Furnham, Adrian, 2003. Belief in a just world: research progress over the past decade. Pers. Indiv. Differ. 34 (5), $795-817$.

Gill, Anthony, 1998. Rendering unto Caesar: the Catholic Church and the State in Latin America. Chicago University Press, Chicago.

Gill, Anthony, 2001. Religion and comparative politics. Annu. Rev. Polit. Sci. 4, 117-138.

Greeley, Andrew M., 2003. Religion in Europe at the End of the Second Millennium. New Brunswick: Transaction publishers.

Grzymala-Busse, Anna, 2012. Why comparative politics should take religion (more) seriously. Annu. Rev. Polit. Sci. 15, 421-442.

Guiso, Luigi, Sapienza, Paola, Zingales, Luigi, 2003. People's opium? Religion and economic attitudes. J. Monetary Econ. 50 (1), $225-282$.

Hayes, Bernadette C., 1995. The impact of religious identification on political attitudes: an international comparison. Sociol. Relig. 56 (2), $177-194$.

Huber, John D., Stanig, Piero, 2011. Church-state separation and redistribution. J. Publ. Econ. 95 (7-8), 828-836.

Hunsberger, Bruce, 1995. Religion and prejudice: the role of religious fundamentalism, quest, and right-wing authoritarianism. J. Soc. Issues 51 (2), 113-129.

Just, Aida, Elena Sandovici, Maria, Listhaug, Ola, 2014. Islam, religiosity, and immigrant political action in western Europe. Soc. Sci. Res. 43 (1), $127-144$.

Kalyvas, Stathis N., 1996. The Rise of Christian Democracy in Europe. Cornell University Press, Ithaca.

Kaplan, Hasan, 2012. Belief in a just world, religiosity and victim blaming. Arch. Psychol. Relig. 34 (3), $397-409$.

Kittilson, Caul, Miki, 2009. Research resources in comparative political behavior. In: Dalton, Russell J., Klingemann, Hans-Dieter (Eds.), The Oxford Handbook of Political Behavior. Oxford University Press, Oxford, pp. 865-895.

Knutsen, Oddbjørn, 2004. Religious denomination and party choice in western Europe: a comparative longitudinal study from Eight countries, 1970-97. Int. Polit. Sci. Rev. 25 (1), 97-128.

Kotler-Berkowitz, Laurence A., 2001. Religion and voting behavior in Great Britain: a reassessment. Br. J. Polit. Sci. 31 (3), $523-554$.

Kuklinski, James H., West, Darrell M., 1981. Economic expectations and voting behavior in United States House and Senate elections. Am. Polit. Sci. Rev. 75 (2), 436-447.

Kunst, Jennifer L., Bjorck, Jeffrey P., Tan, Siang-Yang, 2000. Causal attributions for uncontrollable negative events. J. Psychol. Christianity 19 (1), 47-60.

Layman, Geoffrey C., 1997. Religion and political behavior in the United States. Publ. Opin. Q. 61 (2), $288-316$.

Lerner, Melvin J., 1977. The justice motive: some hypotheses as to its origins and forms. J. Pers. 45 (1), 1-52.

Lerner, Melvin J., 1980. The Belief in a Just World: a Fundamental Delusion. Plenum Press, New York.

McCleary, Rachel M., Barro, Robert J., 2006. Religion and economy. J. Econ. Perspect. 20 (2), 49-72.

McCullough, Michael E., Worthington Jr., Everett L., 1999. Religion and the forgiving personality. J. Pers. 67 (6), $1141-1164$.

Meyer, Katherine, Tope, Daniel, Price, Anne M., 2008. Religion and support for democracy: a cross-national examination. Socio. Spectr. 28 (5), 625-653.

Minkenberg, Michael, 2010. Party politics, religion and elections in western democracies. Comp. Eur. Polit. 8 (4), $385-414$.

Need, Ariana, Graaf, Nan Dirk De, 1996. Losing my religion': a dynamic analysis of leaving the church in The Netherlands. Eur. Socio Rev. 12 (1), 87-99.

Norris, Pippa, 2004. Electoral Engineering. Cambridge University Press, Now York.

Norris, Pippa, Inglehart, Ronald, 2011. Sacred and Secular: Religion and Politics Worldwide, second ed. Cambridge University Press, Cambridge.

Overcash, Wendy S., Calhoun, Lawrence G., Cann, Arnie, Tedeschi, Richard G., 1996. Coping with crises: an Examination of the impact of traumatic events on religious beliefs. J. Genet. Psychol. 157 (4), 455-464.

Pargament, Kenneth I., 1997. The Psychology of Religion and Coping. Guilford Press, New York.

Pargament, Kenneth I., Hahn, June, 1986. God and the just world: causal and coping attributions to God in health situations. J. Sci. Stud. Relig. 25 (2), $193-207$.

Patterson, Eric, 2004. Different religion, different politics? Religion and political attitudes in Argentina and Chile. J. Sci. Stud. Relig. 43 (3), $345-362$.

Raymond, Christopher, 2011. The continued salience of religious voting in the United States, Germany, and Great Britain. Elect. Stud. 30 (1), $125-135$.

Rubin, Zick, Peplau, Letitia Anne, 1975. Who believes in a just world? J. Soc. Issues 31 (3), 65-89.

Ruiter, Stijn, Tubergen, Frank van, 2009. Religious attendance in cross-national perspective: a multilevel analysis of 60 countries. Am. J. Sociol. 115 (3), $863-895$.

Scheve, Kenneth, Stasavage, David, 2006. Religion and preferences for social insurance. Quarterly Journal of Political Science 1 (3), $255-286$.

Schmitter, Philippe C., Karl, Terry Lynn, 1991. What Democracy is... and is not. J. Democr. 2 (3), 75-88.

Smith, Timothy B., McCullough, Michael E., Justin Poll, J., 2003. Religiousness and depression: evidence for a main effect and the moderating influence of stressful life events. Psychol. Bull. 130 (1), 614-636.

Sorrentino, Richard M., Hardy, Jack E., 1974. Religiousness and derogation of an innocent victim. J. Pers. 42 (3), $372-382$.

Stark, Rodney, 1999. Secularization, R.I.P. Sociol. Relig. 60 (3), 249-265.

Stark, Rodney, Finke, Roger, 2000. Acts of Faith: Exploring the Human Side of Religion. University of California Press, Berkeley.

Steenbergen, Marco R., Jones, Bradford S., 2002. Modeling multilevel data structures. Am. J. Polit. Sci. 46 (1), $218-237$.

Stepan, Alfred C., 2000. Religion, democracy, and the "twin tolerations". J. Democr. 11 (4), 37-57.

Szmajke, Andrzej, 1991. Religiousness, belief in a just world, authoritarianism and subjective image of social life in Poland at the decline of real socialism. Pol. Psychol. Bull. 22 (1), 33-42.

Tessler, Mark, 2002. Islam and democracy in the Middle East: the impact of religious orientations on attitudes toward democracy in four arab countries. Comp. Polit. $34,337-354$

Tessler, Mark, 2010. Religion, religiosity and the place of Islam in political life: insights from the arab barometer surveys. Middle E. Law Govern. 2 (2), 221-252. Tilley, James, 2015. We Don't do God'? Religion and party choice in Britain. Br. J. Polit. Sci. 45 (4), 907-927.

Van der Brug, Wouter, Hobolt, Sara B., de Vreese, Claes H., 2009. Religion and party choice in Europe. W. Eur. Polit. 32 (6), $1266-1283$.

Van der Meer, Tom, Paul, Dekker, 2011. Trustworthy states, trusting citizens? A multilevel study into objective and subjective determinants of political trust. In: Zmerli, Sonja, Hooghe, Marc (Eds.), Political Trust: Why Context Matters. ECPR Press, pp. 95-116.

Voas, David, 2009. The rise and fall of fuzzy fidelity in Europe. Eur. Socio Rev. 25 (2), 155-168.

Wald, Kenneth D., Silverman, Adam L., Fridy, Kevin S., 2005. Making sense of religion in political life. Annu. Rev. Polit. Sci. 8, $121-143$.

Wald, Kenneth D., Wilcox, Clyde, 2006. Getting religion: has political science rediscovered the faith factor? Am. Polit. Sci. Rev. 100 (4), 523-529.

Warner, Carolyn M., 2000. Confessions of an Interest Group: the Catholic Church and Political Parties in Europe. Princeton University Press, Princeton. 